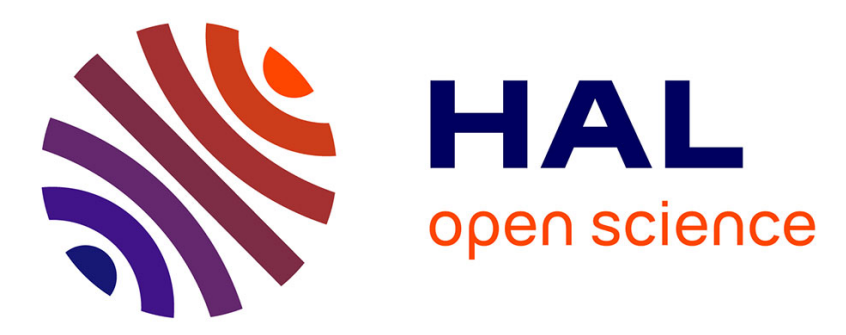

\title{
Influence of yttrium on high temperature behaviour of Fe-Cr-Al-Y alloys
}

F. Clémendot, J. Gras, J. van Duysen

\section{To cite this version:}

F. Clémendot, J. Gras, J. van Duysen. Influence of yttrium on high temperature behaviour of Fe-Cr-Al-Y alloys. Journal de Physique IV Proceedings, 1993, 03 (C9), pp.C9-291-C9-299. 10.1051/jp4:1993928 . jpa-00252366

\section{HAL Id: jpa-00252366 https://hal.science/jpa-00252366}

Submitted on 1 Jan 1993

HAL is a multi-disciplinary open access archive for the deposit and dissemination of scientific research documents, whether they are published or not. The documents may come from teaching and research institutions in France or abroad, or from public or private research centers.
L'archive ouverte pluridisciplinaire HAL, est destinée au dépôt et à la diffusion de documents scientifiques de niveau recherche, publiés ou non, émanant des établissements d'enseignement et de recherche français ou étrangers, des laboratoires publics ou privés. 


\title{
Influence of yttrium on high temperature behaviour of Fe-Cr-Al-Y alloys
}

\author{
F. Clémendot, J.M. Gras and J.C. van Duysen
}

Département Etude des Matériaux, Direction des Etudes et Recherches, Electricité de France, Les Renardières, B.P. $n^{\circ} 1,77250$ Moret/Loing, France

\begin{abstract}
We have studied the oxidation behaviour of three ind ustrial $\mathrm{Fe}-\mathrm{Cr}$-Al alloys (with or without yttrium) at temperatures ranging between 1200 and $1350^{\circ} \mathrm{C}$. At $1200^{\circ} \mathrm{C}$, the behaviour of these alloys is improved as the yttrium content rises. However, for temperatures higher or equal to $1300^{\circ} \mathrm{C}$, the presence of yttrium seems to be detrimental. In particular, the distribution of this element in $\mathrm{YFe}_{9}$ or $\mathrm{Y}_{2} \mathrm{Fe}_{17}$ intermetallic particles allows yttrium to diffuse towards the surface of the product. The high kinetic of this diffusion leads to the formation of oxidized cavities by Kirkendall effect. The results obtained on the $0.14 \%$-yttrium product show that the distribution of this element under the oxidized form could help to avoid this damage.
\end{abstract}

\section{Introduction.}

Fe-Cr-Al refractory alloys present a great resistance to high temperature oxidation. Their high aluminium content $(\approx 5 \%)$ allows the formation of an alumina refractory layer $\left(\mathrm{Al}_{2} \mathrm{O}_{3}\right)$ which protects them. However, the formation of this oxide layer is associated with the development of lateral stresses which are responsible for scaling, particularly during thermal cycling [1-5]. The increase of oxidation kinetics which follows this scaling, decreases the inservice life time of the materials.

The addition of reactive elements such as yttrium which develops stable oxides, improves the adhesion of oxide layers, thus increasing the hot oxidation resistance of these alloys. Many mechanisms have been proposed to explain this improvement: the oxide growth occurs at the metal-oxide interface and not into the oxide layer, voids are supressed at the metal-oxide interface, intergranular "pegs" of yttrium oxide appears under the surface of the metal or yttrium traps sulfur [6-11].

Most of the work concerning high temperature oxidation of the $\mathrm{Fe}-\mathrm{Cr}$-Al alloys, with or without yttrium, has been carried out mainly at temperatures lower or equal to $1100^{\circ} \mathrm{C}$ (rarely at $1200^{\circ} \mathrm{C}$ ) and for relatively short holding times ( $<100$ hours).

The use of these alloys for fabrication of electric resistances for high temperature furnaces has led EDF to study their behaviour in conditions representative of those aimed for in service (temperature between 1200 and $1350^{\circ} \mathrm{C}$, life time of several hundred hours).

This paper describes the results obtained during a comparative study carried out on three industrial alloys provided by Kanthal, Driver-Harris and Imphy: one yttrium-free and two yttrium-containing. In particular, we have shown that at high temperature yttrium can have a detrimental effect on the hot oxydation resistance of this type of alloy, in opposition to what is known at lower temperatures. 


\section{Experimental method.}

All the industrial products were received in the form of $3.25 \mathrm{~mm}$ diameter wires. The investigations have been mainly focussed on yttrium-containing products. The yttrium-free one was studied as reference. The chemical composition of these products is reported in table I.

Table I. - Chemical analysis of studied products (weight \%).

\begin{tabular}{|c|c|c|c|c|c|c|c|c|c|c|}
\cline { 2 - 10 } \multicolumn{1}{c|}{} & C & S & P & N & Si & Ni & Cr & Al & Zr & Y \\
\hline Alloy A & 0,026 & 0,001 & 0,008 & 0,009 & 0,27 & 0,25 & 21.1 & 5,66 & 0,11 & $<0,01$ \\
\hline Alloy B & 0,033 & 0,002 & 0,007 & 0,005 & 0,35 & 0,12 & 16,3 & 4,67 & 0,02 & 0,14 \\
\hline Alloy C & 0,023 & 0,001 & 0,006 & 0,001 & 0,47 & 0,14 & 20,0 & 4,82 & 0,02 & 0,30 \\
\hline
\end{tabular}

Concerning easily oxidable elements (except yttrium), we can notice differences between the silicon and particularly the zirconium contents of the studied products.

The characterization of the as-received products was carried out by optical and scanning electron microscopies. Yttrium-rich phases were identified by energy dispersive X microanalysis. Their distribution and their morphology were determined by image analysis obtained with a scanning electron microscope. The quantitative treatments applied to the particles determined the following parameters: average surface density, average diameter and average interparticle distance.

Accelerated cyclic ageings (Bash and Harsch tests) were carried out according to C31-712 AFNOR standard on $0.65 \mathrm{~mm}$ wire-drawn from the initial products [12]. In this test, the wires are heated by a cyclic electric current (a heating-cooling period $=4 \mathrm{~min}$ ). During this test, we measure the temperature at which the life of the sample lasts between 100 and 160 hours (Bash and Harsch temperature).

Isothermal oxidation tests were carried out in air in a furnace at 1200,1300 and $1350^{\circ} \mathrm{C}$ for times lasting between 100 and 1000 hours. For these tests, no particular preparation of the wires was done. Identification of the formed layers of oxide was determined by X-ray diffraction on the oxidized bulky samples. The structural evolution as well as the distribution of yttrium were studied in the aged products by optical microscopy. Diametral profiles of aluminium and yttrium contents were determined by EDS. For these profiles, each measurement was carried out in a zone wide enough to take into account the yttrium in solid solution or trapped into precipitates.

\section{Experimental results.}

3.1 DistribUTION OF YTTRIUM IN AS RECEIVED CONDITIONS. - In the alloy with $0.14 \%$ of yttrium (alloy B), the element is distributed in two types of phases: an oxide, probably $\mathrm{Y}_{2} \mathrm{O}_{3}$ type, and a $\mathrm{YFe}_{9}$ or $\mathrm{Y}_{2} \mathrm{Fe}_{17}$ type intermetallic phase (Fig. 1). The intermetallic phases are bulky and angular. They are often gathered into clusters and their fractured aspect suggests that they are brittle. Oxides are more dispersed and are always isolated.

In the product containing the highest yttrium content $(0.30 \%$, alloy $\mathrm{C})$, this element is only present in the intermetallic form. The precipitates identified by transmission electron microscopy are hexagonal $(\mathrm{Y}, \mathrm{Al})_{2}(\mathrm{Fe}, \mathrm{Cr})_{17}(a=0.86 \mathrm{~nm} ; c=0.85 \mathrm{~nm})$. 


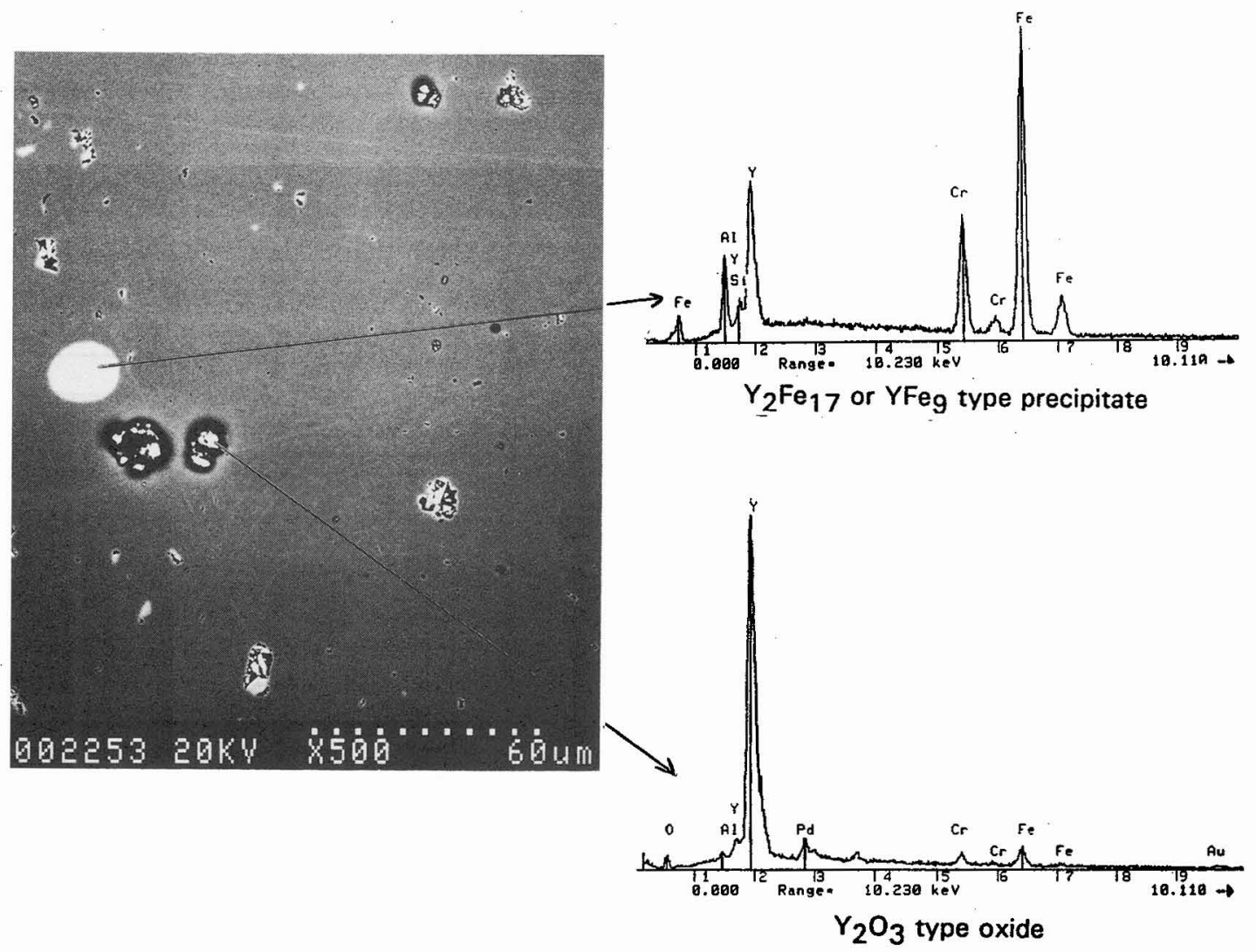

Fig. 1. - Aspect of various yttrium-rich phases in the substrate by scanning electron microscopy and their EDS associated spectra.

The results of the quantitative treatments applied on both the yttrium-rich phases by image analysis are indicated in table II [13].

The results show that the distribution of the yttrium-rich intermetallic phases $\left(\mathrm{YFe}_{9}, \mathrm{Y}_{2} \mathrm{Fe}_{17}\right)$ is similar in alloys B and C. In alloy B, the oxides represent about one third of all observed yttrium-rich phases.

Table II. - Quantitative morphologic treatments of the yttrium-rich phases.

\begin{tabular}{|c|c|c|c|}
\cline { 2 - 4 } \multicolumn{1}{c|}{} & $\begin{array}{c}\text { surface } \\
\text { density }(\%)\end{array}$ & $\begin{array}{c}\text { Average } \\
\text { diameter }(\mu \mathrm{m})\end{array}$ & $\begin{array}{c}\text { Interparticule average } \\
\text { distance }(\mu \mathrm{m})\end{array}$ \\
\hline Alloy B & $\begin{array}{c}2(\sigma=1.0) \mathrm{YFe}_{9} \\
1(\sigma=0.4) \mathrm{Y}_{2} \mathrm{O}_{3}\end{array}$ & $5.1(\sigma=4.0)$ & $18(\sigma=9.5)$ \\
\hline Alloy C & $2.7(\sigma=0.8) \mathrm{YFe}_{9}$ & $5.0(\sigma=3.4)$ & $16.0(\sigma=7.7)$ \\
\hline
\end{tabular}


3.2 ACCELERATED CYCLING AGEING. - The accelerated cycling tests were carried out in two ways. For all the products, Bash and Harsch's temperature as well as the life time during intensive thermal cycling at $1200^{\circ} \mathrm{C}$ were measured. The results are indicated in table III.

Table III. - Results of cyclic ageings.

\begin{tabular}{|c|c|c|}
\cline { 2 - 3 } \multicolumn{1}{c|}{} & $\begin{array}{c}\text { BASH AND HARSCH'S } \\
\text { TEMPERATURE }\left({ }^{\circ} \mathrm{C}\right)\end{array}$ & $\begin{array}{c}\text { IIFE TIME } \\
\text { AT } 1200^{\circ} \mathrm{C}(\mathrm{h})\end{array}$ \\
\hline ALLOY A $-Y \approx 08$ & 1350 & 115 \\
\hline ALLOY B $-Y=0.148$ & 1300 & 127 \\
\hline ALLOY C $-Y=0.308$ & 1300 & 161 \\
\hline
\end{tabular}

The Bash and Harsch's temperature of the yttrium-free alloy is higher than that of both yttrium-containing alloys. This means that the resistance to cyclic oxidation at high temperatures $\left(1300-1350^{\circ} \mathrm{C}\right)$ of the studied Fe-Cr-Al-Y alloys is lower than that of Fe-Cr-Al. This result has been already observed on other similar products of various origins [14, 15]. On the other hand, at $1200^{\circ} \mathrm{C}$, the life time during thermal cycling increases as the yttrium content rises. At this temperature, the beneficial effect of yttrium on oxidation resistance of the $\mathrm{Fe}-\mathrm{Cr}-\mathrm{Al}$ is confirmed.

3.3 ISOTHERMAL AGEINGS. - The oxide layer of the ytrium-free alloy tends to spall, for all the studied ageing heat treatments. After all the holdings at $1200^{\circ} \mathrm{C}$ or for those up to $600 \mathrm{~h}$ at $1350^{\circ} \mathrm{C}$, the yttrium-containing alloys are covered with an homogeneous layer of a grey oxide with a tarnished aspect. However, after ageing at $1350^{\circ} \mathrm{C}$ for holding time lower or equal to $600 \mathrm{~h}$, the oxide layer of the yttrium-containing alloys presents spalling similar to those observed on the yttrium-free alloy.

After an ageing for $1000 \mathrm{~h}$ at 1300 or $1350^{\circ} \mathrm{C}$, alloy $\mathrm{C}$ is completely oxidized. In the same conditions of treatment, alloys $\mathrm{A}$ and $\mathrm{B}$ are only oxidized on their surfaces.

The results of X-ray diffraction performed on the oxide developed after ageing for $1000 \mathrm{~h}$ at $1200^{\circ} \mathrm{C}, 600 \mathrm{~h}$ at $1300^{\circ} \mathrm{C}$ and $1000 \mathrm{~h}$ at $1300^{\circ} \mathrm{C}$ are presented in table $\mathrm{IV}$.

Table IV. - Identification of the surface oxides by X-ray diffraction.

\begin{tabular}{|c|c|c|c|c|c|}
\hline Product & \multicolumn{2}{|c|}{ Alloy $\mathrm{A}$} & \multicolumn{2}{c|}{ Alloys B and $\mathrm{C}$} & Alloy C \\
\hline Ageing & $\begin{array}{c}1000 \mathrm{~h} \\
1200^{\circ} \mathrm{C}\end{array}$ & $\begin{array}{c}600 \mathrm{~h} \\
1300^{\circ} \mathrm{C}\end{array}$ & $\begin{array}{c}1000 \mathrm{~h} \\
1200^{\circ} \mathrm{C}\end{array}$ & $\begin{array}{c}600 \mathrm{~h} \\
1300^{\circ} \mathrm{C}\end{array}$ & $\begin{array}{c}1000 \mathrm{~h} \\
1300^{\circ} \mathrm{C}\end{array}$ \\
\hline Identification & $\alpha \mathrm{Al}_{2} \mathrm{O}_{3}$ & $\alpha \mathrm{Al}_{2} \mathrm{O}_{3}$ & $\begin{array}{c}\alpha \mathrm{Al}_{2} \mathrm{O}_{3} \\
\mathrm{YAlO}_{3}\end{array}$ & $\begin{array}{c}\alpha \mathrm{Al}_{2} \mathrm{O}_{3} \\
\mathrm{YAlO}_{3}\end{array}$ & $\begin{array}{c}\mathrm{Cr}_{1,3} \mathrm{Fe}_{0,7} \mathrm{O}_{3} \\
\mathrm{Fe}_{2} \mathrm{O}_{3}\end{array}$ \\
\hline
\end{tabular}

$\left(^{*}\right)$ After this ageing, alloy $\mathrm{C}$ is completely oxidized. 
The oxide layers are made up of alumina for the yttrium-free alloy and of alumina as well as aluminium and yttrium mixed oxide for the yttrium-containing alloys. The alloy $\mathrm{C}$ aged for $1000 \mathrm{~h}$ at $1300^{\circ} \mathrm{C}$ (which is completely oxidized) seems to be completely composed of iron and chromium-rich oxides.

The aspect of the oxide layer observed on metallographic sections (except when the product is completely oxidized) is dependent on the presence or the absence of yttrium within the alloy. On the yttrium-free alloy (alloy A), the oxide layer has a convoluted profil and shows many flakes, whereas on the yttrium-containing alloys, it is more regular and more compact. In the latter, intergranular "pegs" of oxide were observed (Fig. 2). As expected, these oxides are very rich in yttrium.
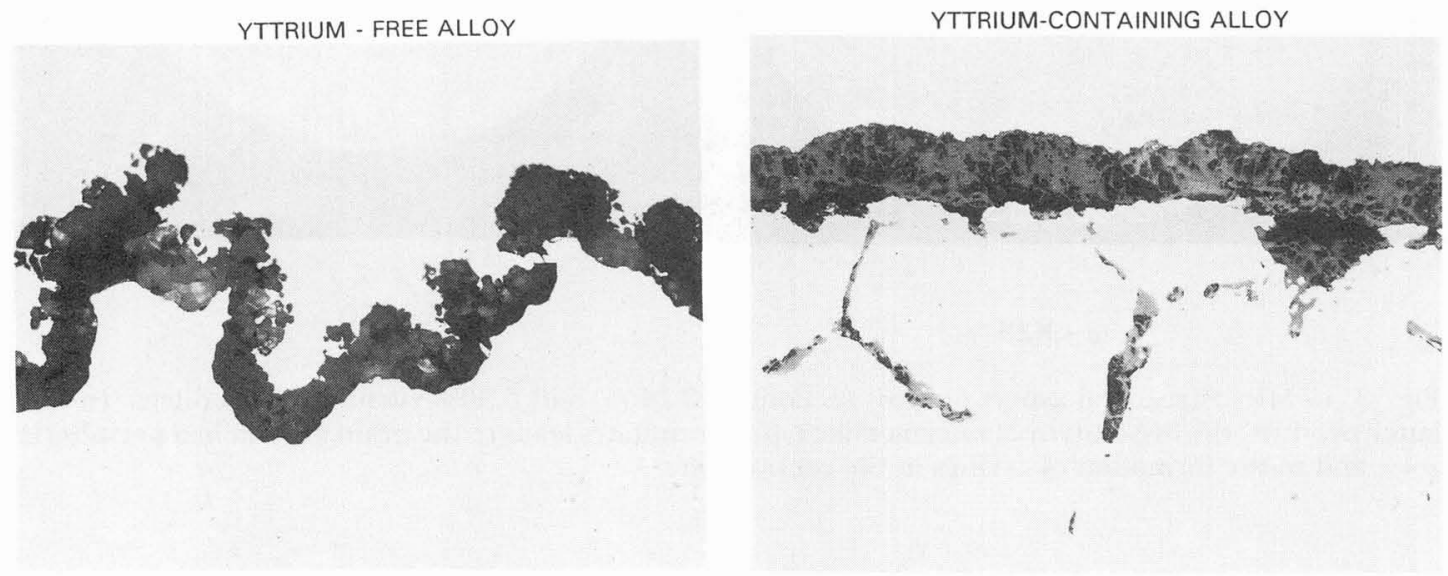

Fig. 2. $-\times 400$. Aspect of oxide layers observed on metallographic sections in yttrium-free alloy and in yttrium-containing alloys.

The metallographic investigations show that in the yttrium-free alloy (alloy A) the grain size remains homogeneous throughout the cross-section of the wire. In the yttrium-containing alloys, the grain size is not homogeneous: the grains are smaller in a central zone than in the rest of the section (Fig. 3). The diameter of the central zone with small grains decreases when the holding time and/or the ageing temperature increase(s). This zone totally disappears after ageing at $1350^{\circ} \mathrm{C}$.

We also notice a dissolution of the $\mathrm{Y}_{2} \mathrm{Fe}_{17}$ phases in the zone with coarse grains and their coalescence in the central zone with small grains. In this latter zone, the YFeg precipitates seem to have blocked the migration of the grain boundaries, thus limiting the grain growth (Fig. 3b). At $1350^{\circ} \mathrm{C}$, the $\mathrm{Y}_{2} \mathrm{Fe}_{17}$ type precipitates have completely disappeared. However, the $\mathrm{Y}_{2} \mathrm{O}_{3}$ type oxides (only present in alloy $\mathrm{B}$ ) do not evolve during the ageing heat treatments.

In addition to this evolution of the precipitation, we notice the development of voids covered with oxide (Fig. 3b). These voids may be observed after short holding at relatively low temperature $\left(100 \mathrm{~h}\right.$ at $\left.1200^{\circ} \mathrm{C}\right)$. Their size and number increase as the temperature and the holding time rise. They are very large and numerous after the $600 \mathrm{~h}$ ageing at $1350{ }^{\circ} \mathrm{C}$.

For each ageing, the aluminium and yttrium radial distribution (except the oxide layer) determined by EDS is pratically homogeneous in all the studied products. However, we 


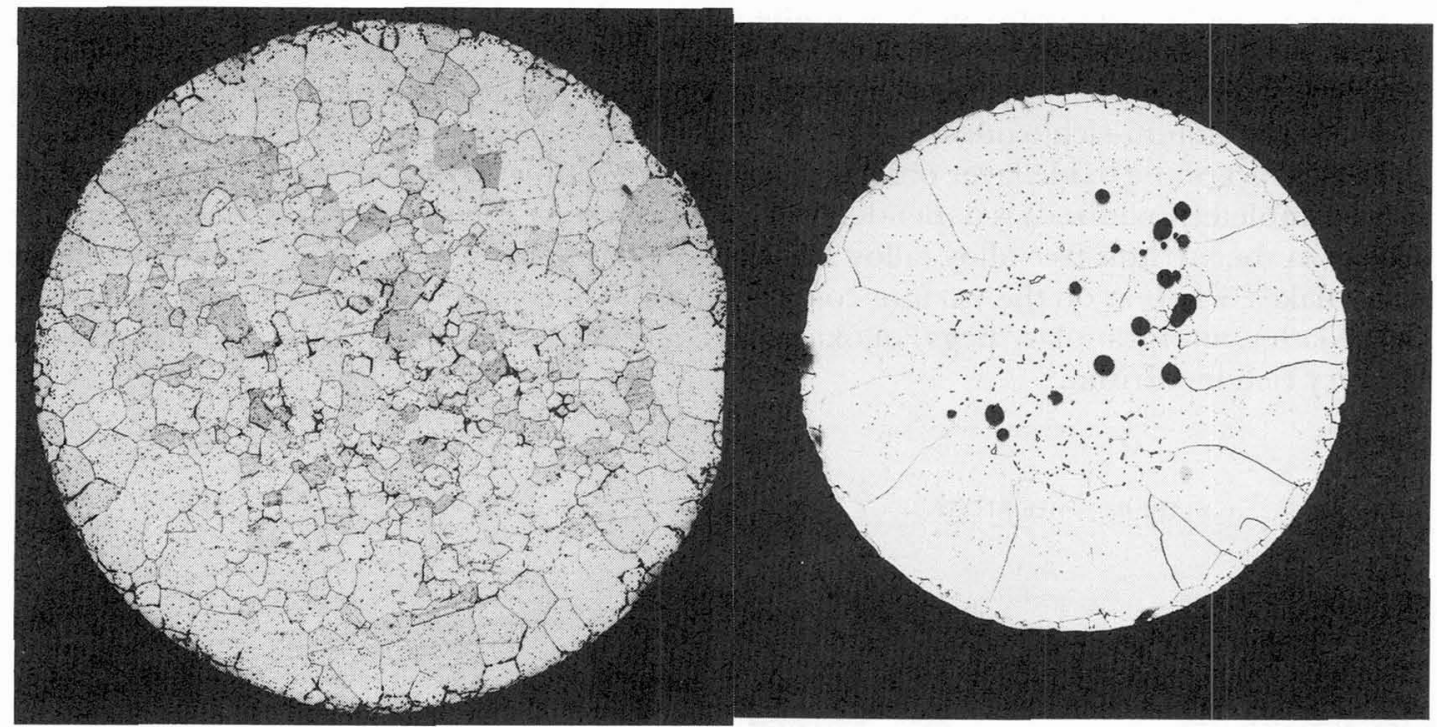

a $-\times 25$

b- $\times 20$

Fig. 3. - Microstructural aspect of cross sections of 0.14 (a) and $0.30 \%$-yttrium (b) products. In this latter product, the dissolution of intermetallic type precipitates leads to the grain growth in a peripheric zone and to the formation of cavities in the central zone.

observe a decrease of the content levels of these elements in relation to the ageing parameters. These levels decrease as the temperature and holding time increase.

For all holding times at $1200^{\circ} \mathrm{C}$ and up to $600 \mathrm{~h}$ at $1300^{\circ} \mathrm{C}$, the loss of aluminium is similar for both types of products (with or without yttrium). However, at $1350^{\circ} \mathrm{C}$, the consumption of aluminium is much greater in alloy C. than in alloys A et B (Fig. 4a).

The loss of yttrium of alloy $B$ is gradual whereas that of alloy $C$ mainly occurs at the beginning of holdings in temperature (Fig. 4). For the shortest holding time $(100 \mathrm{~h})$, the yttrium loss in alloy $\mathrm{C}$ is relatively higher than for alloy $\mathrm{B}$.

\section{Discussion.}

4.1 OXIDATION RESISTANCE. - The beneficial effect of yttrium on the oxide layer adhesion of Fe-Cr-Al alloys is confirmed at $1200^{\circ} \mathrm{C}$. However, at higher temperatures $\left(1300,1350^{\circ} \mathrm{C}\right)$, the oxidation resistance (particularly during cycling) of the yttrium-containing alloys is lower than that of the yttrium-free ones.

Concerning the yttrium-free alloy, we do not notice any influence of zirconium on the mechanism of oxidation. In this alloy, we have shown that zirconium is trapped in refractory nitrides and the zirconium content in this free-yttrium alloy is practically constant after the various ageings. We have not remarked any significant effect of silicon on the oxidation of the studied alloys. Nevertheless, since the silicon contents are similar in the studied alloys, it is probable that this eventual effect is equivalent in these three alloys. 

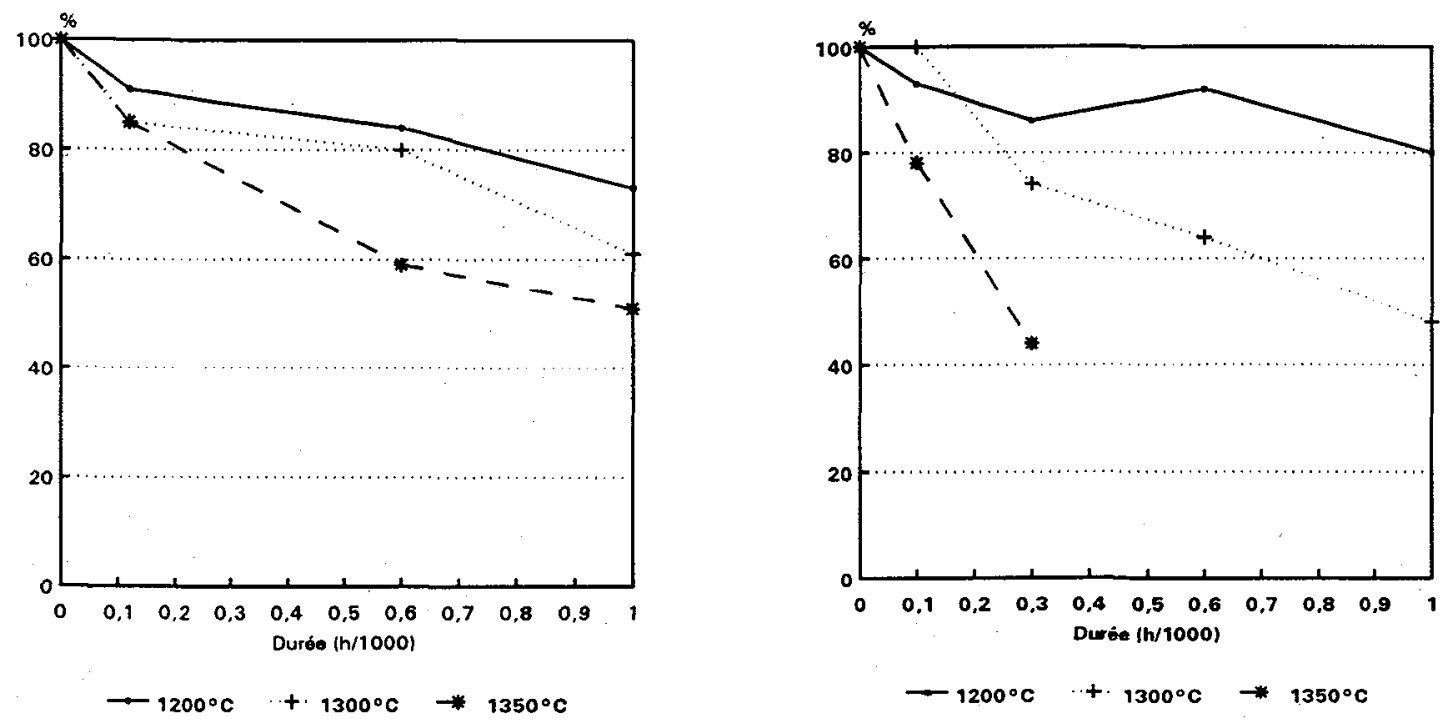

$0,30 \%$ YTTRIUM-ALLOY
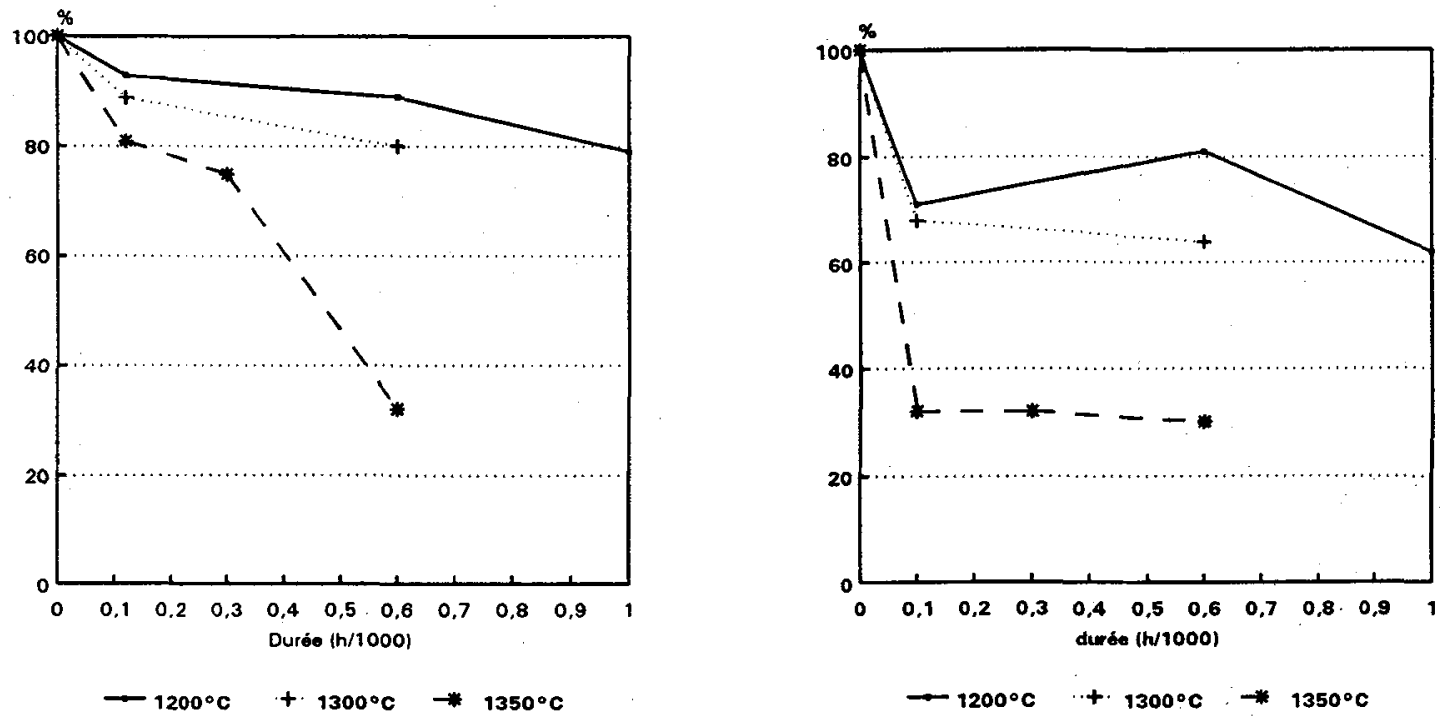

a

b

Fig. 4. - Evolution of average aluminium (a) and yttrium (b) content in the substrate in relation to ageings parameters in the two yttrium-containing alloys (initial content $=100 \%$ ). 
4.2 Evolution Of YTTRIUM DURING AGEING. - In the studied Fe-Cr-Al alloys, yttrium is distributed into two types of phases: a $\mathrm{Y}_{2} \mathrm{O}_{3}$ type oxide or an intermetallic phase $\left(\mathrm{YFe}_{9}\right.$ or $\mathrm{Y}_{2} \mathrm{Fe}_{17}$ ). The oxide particles, thermodynamically very stable, do not evolve during ageing. In contrast, the intermetallic particles are dissolved or coalesce. The dissolution takes place at first near the surface of the product. It is at the origin of the observed heterogeneous growth of grain. Yttrium having a great affinity with oxygen diffuses towards the surface where it is oxidized. This diffusion, probably intergranular, favours the formation of the $\mathrm{YAlO}_{3}$ "pegs", observed near the surface of the wires. Nevertheless, at the studied temperatures this pegging does not seem to have the beneficial effect on the resistance of oxidation observed at lowest temperatures. It is possible that the induced stresses increase as the temperature rises. This could overlap the effect of yttrium.

4.3 DeVElopment Of CAVITIES IN THE 0.30\% yTtRium PRoduct. - The development of cavities in the central zone of product $\mathrm{C}$ can be explained in the following way. The migration of yttrium towards the surface is probably very quick and cannot be balanced by the diffusion of the other elements. It results in a flow of vacancies between the surface and the core of the product (Kirkendall effect). The vacancies condense in the zones close to the $\mathrm{YFe}_{9}$ type particles to form voids.

It seems that the avidity of the void surfaces for oxygen induces the intergranular diffusion of this element towards the core of the product. This internal oxidation evolves in the same way as that developed on the surface and therefore increases the total consumption of aluminium. The growth of this internal oxide leads at last to the total destruction of the product. Examinations by TEM are under way to tend to understand the mechanism of this degradation.

4.4 Difference. Of THE Behaviour BeTWEen alloys B AND C. - Alloys B and C have some structural differences. Nominal yttrium content of alloy $\mathrm{B}(0.14 \%)$ is lower than that of alloy $\mathrm{C}(0.30 \%)$. Yttrium is distributed in both $\mathrm{Y}_{2} \mathrm{O}_{3}$ and $\mathrm{Y}_{2} \mathrm{Fe}_{17}$ particles for alloy $\mathrm{B}$ but only in $\mathrm{Y}_{2} \mathrm{Fe}_{17}$ particles for alloy $\mathrm{C}$. Since only $\mathrm{Y}_{2} \mathrm{Fe}_{17}$ phases are dissolved during ageing, the quantity of yttrium which can potentially diffuse towards the surface will be about $0.04 \%$ in alloy $\mathrm{B}$, in respect to its initial content and to the ratio of both the $\mathrm{Y}_{2} \mathrm{O}_{3}$ and $\mathrm{YFe}_{9}$ phases. For alloy $\mathrm{C}$, which contains only the $\mathrm{Y}_{2} \mathrm{Fe}_{17}$ phase, the quantity of yttrium which can diffuse will be close to the nominal content $(0.30 \%)$, since the very small content initially in solution into the matrix is negligible. This difference between the quantity of yttrium which can go into solid solution and diffuse to the surface may explain why cavities appear in product $\mathrm{C}$ not in product $B$.

\section{Conclusion.}

The study of the behaviour of the high temperature oxidation of Fe-Cr-Al type alloys (with or without yttrium) used for the fabrication of high temperature furnace resistances (between 1200 and $1350^{\circ} \mathrm{C}$ ) leads to the following conclusions.

At $1200^{\circ} \mathrm{C}$, the behaviour of these alloys is improved as the yttrium content rises. However, for temperatures higher or equal to $1300^{\circ} \mathrm{C}$, the presence of yttrium seems to be detrimental. In particular, the distribution of this element in $\mathrm{YFe}_{9}$ or $\mathrm{Y}_{2} \mathrm{Fe}_{17}$ intermetallic particles allows yttrium to diffuse towards the surface of the product. The high kinetic of this diffusion leads 
to the formation of oxidized cavities by Kirkendall effect. The results obtained on the $0.14 \%$ yttrrium product show that the distribution of this element in the oxidized from could help to avoid this damage.

\section{References}

[1] TOMASZEWICZ P., WALLWORK G.R., Iron-aluminium alloys: a review of their oxidation, School of metallurgy university of New South Wales (Australia, 1979) pp. 76-105.

[2] Strott F.H., Wood G.G., Golightly F.A., Corros. Sci. 19 (1979) 869-887.

[3] STotT F.H., Wood G.C., Golightly F.A., Corros. Sci. 19 (1979) 889-906.

[4] Taniguchi S., Shibata T., Oxid. Met. 32 (1989) 391-404.

[5] Sigler D.R., Oxid. Met. 32 (1989) 337-355.

[6] Ben abderraziK G., Mét. Corros. Ind., LXI LXII (733/748).

[7] SIGLER D.R., Oxid. Met. 36 (1991) 57-80.

[8] VERNON-PARRY K.D., GrovenOR C.R.M., NEEDHAM N., ENGlish T., Mater. Sci. Technol. 4 (1988) 461-464.

[9] Moseley P.T., Hyde K.R., Bellamy B.M., Tappin G., Corros. Sci. 24 (1984) 547-565.

[10] Lagrange M.H., Huntz A.M., Davidson J.H., Corros. Sci. 24 (1984) 613-627.

[11] Ramanarayanan T.A., Ayer R., Petkovic-luton R., Leta D.P., Oxid. Met. 29 (1988) 445-472.

[12] Norme AFNOR C 31-712, Alliages pour résistances électriques de chauffage en nickelchrome, fer-nickel-chrome et fer-chrome-aluminium. Méthode d'essai par vieillissement accéléré permettant un classement des alliages d'après leur comportement à haute température, 15/02/76.

[13] ARnoldi F., Clemendot F., Lina A., Etude morphologique de la répartition de l'yttrium dans des alliages de type $\mathrm{Fe}-\mathrm{Cr}-\mathrm{Al}-\mathrm{Y}$, par analyse d'image, Rapport EDF à paraître.

[14] Clemendot F., VAN DUySEN, Etude métallurgique d'alliages métalliques pour résistances de fours haute température. Alliages $\mathrm{Fe}-\mathrm{Cr}-\mathrm{Al}$ (Y) et Ni-Cr-Al-Y développés par Kanthal, Driver-Harris et Cabot, Rapport EDF HT-41/PV D 703-A (1989).

[15] Clemendot F., Etude métallurgique d'alliages métalliques pour résistances de fours haute température. Alliages Fe-Cr-Al et Fe-Cr-Al-Y développés par Imphy, Rapport EDF HT/41 NTE 1358 (1991). 